\title{
State of the art of the application of seismic isolation and energy dissipation systems to civil structures in Cyprus
}

\author{
P. Komodromos \& M. C. Phocas \\ Department of Civil and Environmental Engineering, \\ University of Cyprus, Cyprus
}

\begin{abstract}
Structural control through base isolation and energy dissipation systems has been increasingly implemented internationally in recent years and has proven to be one of the most promising strategies for the earthquake safety of structures. Nevertheless, only recently there have been applications of passive structural control in Cyprus. Whereas the integration of passive damping devices within a structure aims at the energy dissipation within specific structural zones, the concept of base isolation aims at the minimization of the input seismic energy above the isolation level. This paper gives an overview of the current application status of the control techniques to some civil structures in Cyprus: a multi-storey $\mathrm{r} / \mathrm{c}$ building of the Cyprus Sport Organization with steel diagonals and viscous dampers; a cable suspended footbridge with tuned mass dampers; three commercial buildings of steel bare rigid frames and braced frames, where base isolators in the form of high damping rubber bearings, elastomeric bearings and friction pendulum bearings are placed on top of the basement columns; a retrofit planned for a multi-storey building for the Telecommunications Authority of Cyprus, partly to be supported on friction seismic isolation devices; and four highway bridges, supported on either elastomeric bearings with dual lead cores or on friction pendulum bearings.
\end{abstract}

Keywords: structural control, seismic isolation, energy dissipation, seismic performance. 


\section{Introduction}

Cyprus has a long historical record of damaging earthquakes and life loss. Compared to many areas of the world, the pre-1900 earthquake history of Cyprus is relatively well known back to at least $92 \mathrm{BC}$ (Ambraseys [1]), although the first seismograph was installed in 1984 and the seismograph network was upgraded in two subsequent phases 10 and 5 years ago, respectively. Most of what is known about the seismicity of Cyprus since the 20th Century is found in the records of regional seismic networks in the central and eastern Mediterranean area and from the international earthquake centres.

The national earthquake resistance regulations comply with Eurocode 8, based on the capacity design of the structures according to the ductility classification of the systems. Major improvement in the national annex of the code is the redefinition of the seismic zones in Cyprus with substantial increase of the design acceleration for elastic response.

In further improving the earthquake resistance of the structures within acceptable ranges, passive control may be achieved with the integration of damping devices into the structure or the isolation of the building from the ground excitations. In the first case the energy dissipation process is controlled within the structure. In the second case the input earthquake energy of the structure is itself minimized, and the earthquake impacts are transmitted from the low tuned bearings to the building as smaller shear forces, through oscillations of lower frequency. The deformations are confined at the isolation level. The current status of application of the control techniques in building and bridge design in Cyprus is presented.

\section{Seismicity}

\subsection{Regional tectonics}

Cyprus lies on the southern part of the diffuse boundary between the African and Eurasian plates in a general zone of shortening, which extends between the Gulf of Antalia in the west and the Gulf of Iskenderun in the east. In the west the Cyprean Arc meets the eastern end of the Hellenic Arc under southern Turkey in an area with subcrustal and intermediate depth earthquakes. In the east it joins the east Anatolian fault zone, which extends north-eastwards through Turkey from the continuation of the Dead Sea rift system up the Syrian coast, fig. 1. Hence, Cyprus lies near the junctures of several tectonic elements.

In the past Cyprus was affected by many earthquakes, although the level of earthquake activity in Cyprus can be considered to be less than that of high seismicity regions of Greece and Turkey. Historical records indicate that from $1500 \mathrm{BC}$ to $1900 \mathrm{AD}$ at least 26 earthquakes caused severe damage or destroyed ancient cities situated mainly along the coastal area of the west, south and southeast part of Cyprus. During the last century, Cyprus was affected by approximately 28 earthquakes with a magnitude greater than 4.7 on the Richter scale. This gives approximately a return period of 120 years for a destructive 


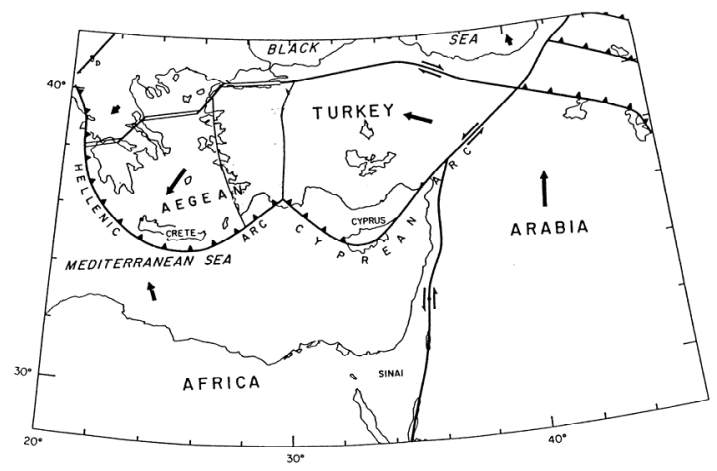

Figure 1: Configuration of plates in the east Mediterranean and surrounding areas (McKenzie [2]).

earthquake with maximum intensity VIII on the Modified Mercalli scale (Ambraseys and Adams [3]). At least four of these earthquakes were destructive, as follows:

- The earthquake of the 20th of January 1941 of magnitude 6.5 that caused extensive damage in the eastern part of Cyprus, mainly at Paralimni area.

- The earthquake of the 10th of September 1953 of magnitude 6.5 that struck the district of Paphos, south west of Cyprus.

- The earthquake of the 23rd of February 1995 of magnitude 5.8 that occurred in the Paphos region. The cost of damage was estimated to be 5.1 million Euros.

- The earthquake of the 9th of October 1996 of magnitude 6.5 that had its epicentre offshore, $50 \mathrm{~km}$ south west from Paphos. Aftershocks followed for three months until January 1997. Ten of these had a magnitude between 5.0 and 5.8. The cost of damage was estimated to be 3.4 million Euros.

As regards the earthquake activity distribution there is predominance in southeast direction of the island. To the northwest of the island there is an area of lower activity with quiescence for over 100 years, and the active area in the Gulf of Antalia. The fact that the southwest coast of Cyprus from Paphos to Limassol seems to be more seismically active than the rest of the island along the entire historic time is obviously due to its proximity to the collision zone. In general, earthquake focal depths in the Cyprus region range from very shallow depths to over $100 \mathrm{~km}$. The determination of focal depth is complex, particularly before any installation of local seismograph stations in 1997. Based on the earthquake data found for 1964 and later (Ambraseys and Adams [3]), there is no strong evidence for sub-crustal foci beneath the island or to its East, but in the northwest part of the island. It could be confirmed that the seismicity in the Gulf of Antalia includes intermediate depth earthquakes, extending to depths of approximately $100 \mathrm{~km}$, as would be expected from the continuation of such activity from the Helenic Arc. There is a general trend for depth to increase towards the northeast. For the 20th Century the main energy release was in the Cyprus region itself. No clear evidence could be found for sub-crustal events. 
Regarding the chronological level of activity, there is a higher level during the early decades of the 20th Century. In addition, the activity is not uniform with time, half of the events registered occurred in the 20-year period 19181937, and the last three decades since 1960 contain only six events. For the northwest part of the region, in the Gulf of Antalia, all 16 events found, occurred after 1924, while the activity was highest in the 1920s and 1930s.

\subsection{National Earthquake Regulation EC 8}

The Type 1 elastic response spectrum as adopted in the Cyprus National Annex CYS EN 1998-1:2005, of Eurocode 8: Design of Structures for Earthquake Resistance [4], is specified for ground types A to E to represent the horizontal components of the seismic action. The definition of the reference peak ground acceleration on Type A ground, $\alpha \mathrm{gR}$ is according to the seismic zonation map of Cyprus as shown in fig 2 , accounting to a value of $0.25 \mathrm{~g}$.

\section{Structural control techniques}

\subsection{Applications}

Only recently there have been plans or practical implementations of structural control techniques in Cyprus, including the following projects:

- A multi-storey r/c building of the Cyprus Sport Organization with steel diagonals and viscous dampers.

- A cable suspended footbridge above the highway with tuned mass dampers at the supports.
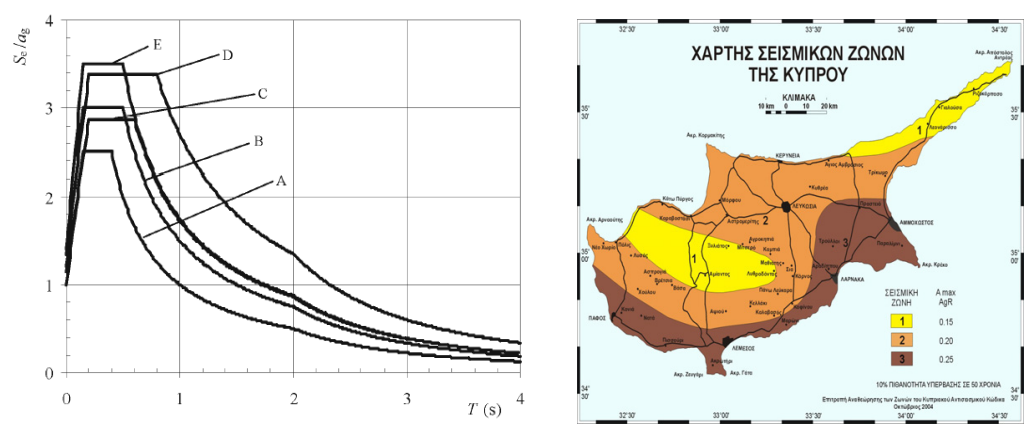

Figure 2: $\quad$ Recommended type 1 elastic response spectrum for ground types A to E for 5\% damping, CYS EN 1998-1:2005 and seismic zonation map of Cyprus, CYS EN 1998-1:2005.

- A commercial building centre, where base isolators as high damping rubber bearings are placed on top of the basement columns.

- A commercial building, with elastomeric bearings and friction pendulum bearings. 
- The retrofit for a multi-storey building for the Telecommunications Authority of Cyprus, partly to be supported on friction seismic isolation devices.

- Highway bridges, supported on elastomeric bearings with dual lead cores.

- Highway bridges, supported on friction pendulum bearings.

\subsubsection{Energy dissipation systems}

The administration building of the Cyprus Athletic Organization is a 3-storey building with an almost rectangular shape. The building consists of two externally positioned parts in the longitudinal direction, interconnected in the middle zone through a central core, fig. 3 . The ground floor area is almost open. The structure of the building consists of $\mathrm{r} / \mathrm{c}$ frames and the shear walls of the core. The frames at the ground floor are equipped with scissor-jack-dampers for earthquake resistance (Sigaher and Constantinou [5]).

The applied system magnifies through its configuration the damper displacement for a given inter-storey drift and the damper force output delivered to the structural frame. The system thus extends the applicability of damping devices to cases of small inter-storey deflections, such as stiff structures under seismic loading. In addition, the scissor-jack damping system allows for open spaces at the ground level through its compactness and near-vertical installation.
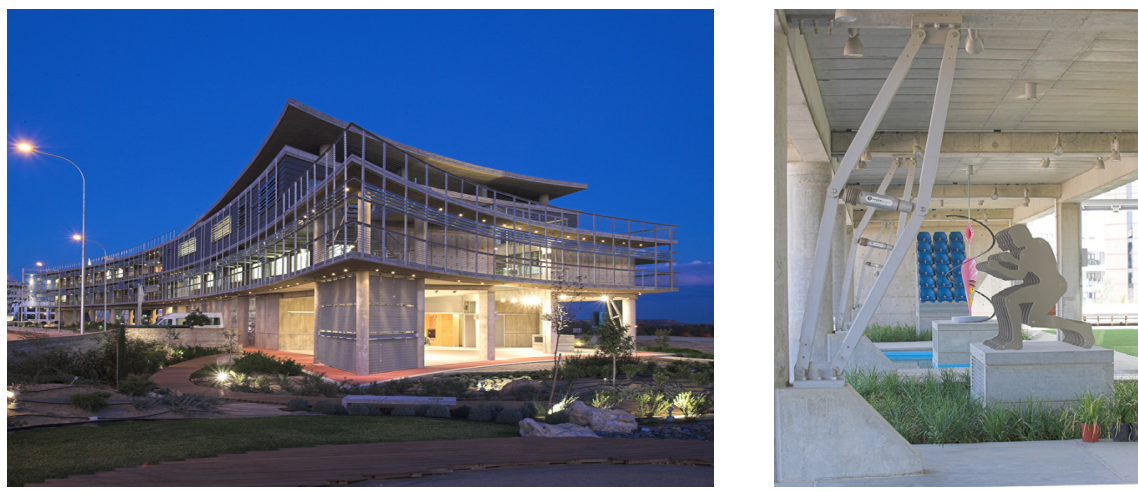

Figure 3: Administration building of the Cyprus Sport Organization equipped with Scissor-Jack-Dampers.

The footbridge at the highway knot of Saint Athanasios, north of Limassol, has a width of $8.5 \mathrm{~m}$ and spans $48 \mathrm{~m}$ free, fig. 4 . Two longitudinal, primary girders are suspended through eight cables from two inclined masts at the sides, of a height of $10 \mathrm{~m}$. The primary girders are supported at the ends on tuned mass dampers for the reduction of the relative displacements of the structure under live loads. The steel structure has been designed to withstand elastically a maximum ground acceleration of $0.25 \mathrm{~g}$.

\subsubsection{Base isolation}

A commercial building centre with two building sections (IKEA premises and the Cyprus Mall) with an area of $40,000 \mathrm{~m}^{2}$, is supported on high damping 
rubber bearings (HDRB), fig. 5. The elastomeric bearings have vertical load capacities ranging from 2.9 to $9.1 \mathrm{MN}$. The maximum relative horizontal displacement of the bearings is $80 \mathrm{~mm}$, while their effective stiffness varies from 2.5 to $3.5 \mathrm{MN} / \mathrm{m}$. The designers provided a seismic buffer in case the provided clearance around the building is exceeded in an earthquake event.
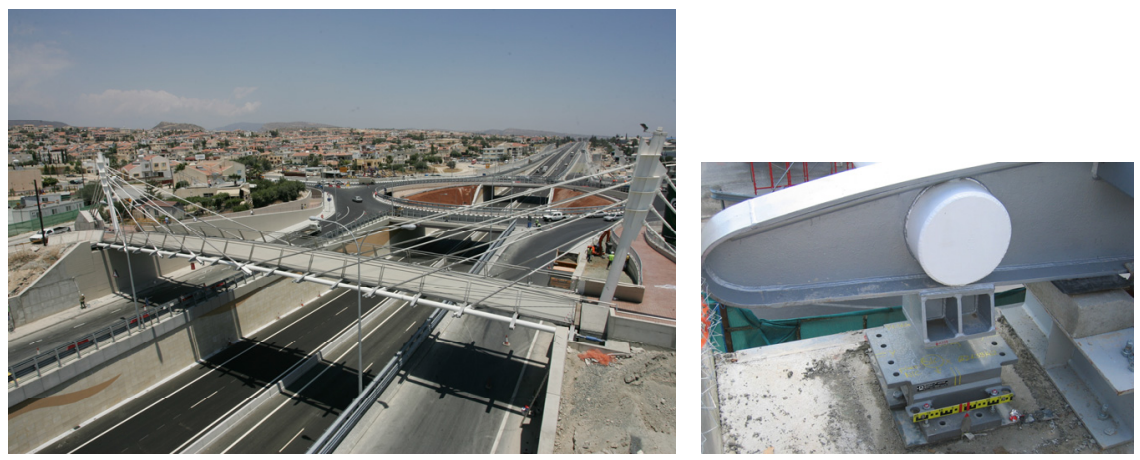

Figure 4: Cable suspended steel footbridge at Saint Athanasios highway knot with tuned mass dampers at the supports.

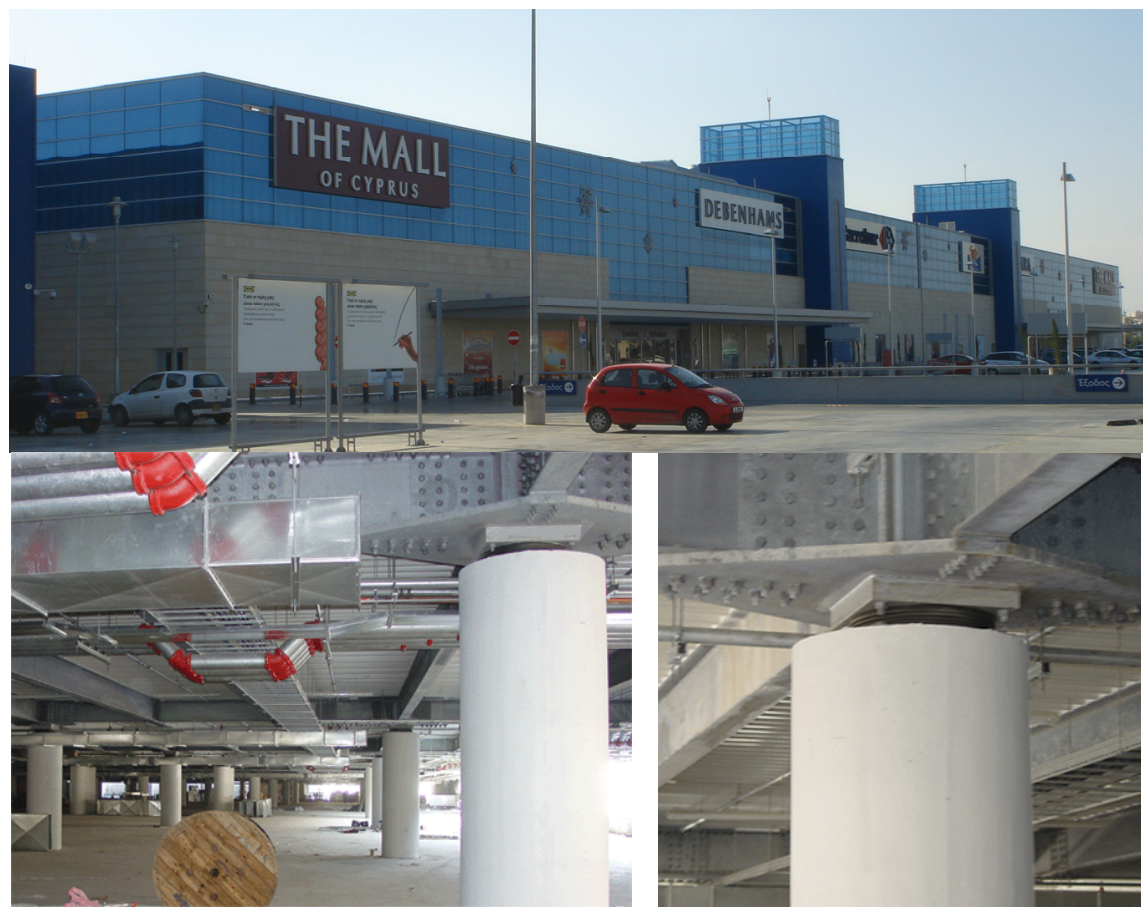

Figure 5: Shopping mall supported on high damping rubber bearings. 
Another commercial two-storey building at the area is being constructed in steel, fig. 6 . The storey structure above ground level consists mainly of storey frames that are additionally braced. Longitudinally the primary beams are partly suspended from the columns, from the upper storey. The relative flexible upper structure is supported on the $\mathrm{r} / \mathrm{c}$ underground storey over elastomeric bearings with seismic buffers and friction pendulum bearings.

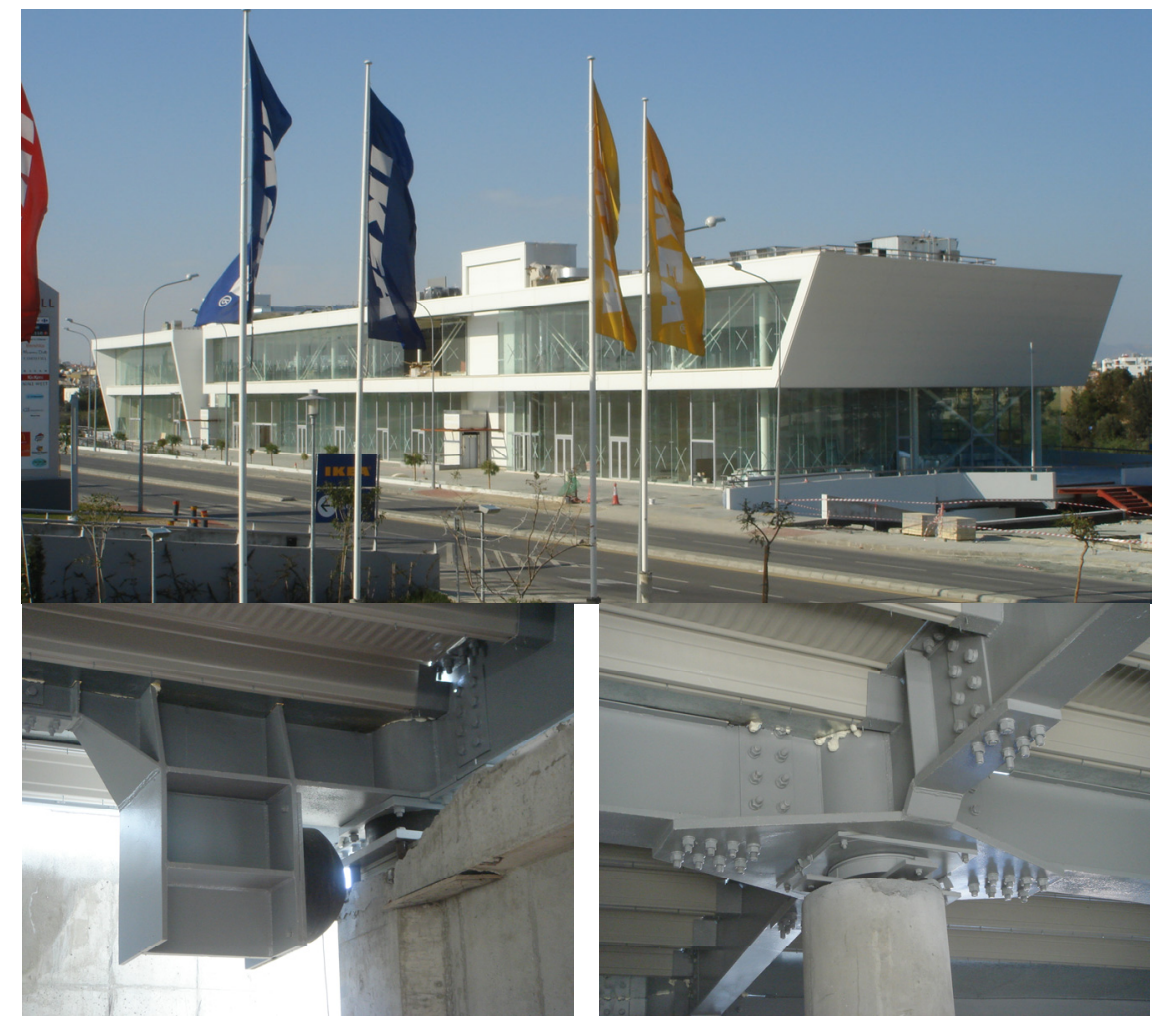

Figure 6: Commercial building with elastomeric bearings and friction pendulum bearings.

The central administration building of the Cyprus Telecommunications Authority was designed in 1978 according to the national earthquake resistance code provisions of that time. A design acceleration of $0.04 \mathrm{~g}$ for elastic response was taken into account. The 5 -storey building with hexagonal form has a nonuniform stiffness distribution. The structure of each rectangular part forming a side of the hexagon consists of $\mathrm{r} / \mathrm{c}$ frames with shear walls at the end of each side, as shown in fig. 7. The period of the fixed supported building is $0.49 \mathrm{~s}$.

The retrofit of the building refers to an acceleration value of $0.25 \mathrm{~g}$ (Sophocleous et al. [6]). Through introduction of seismic isolation - friction pendulum bearings - at the ground level, the structure will develop exclusively translational modes without any substantial torsional effects. The periods of the 
isolated system in the two main directions are calculated at $1.60 \mathrm{~s}$ and $1.57 \mathrm{~s}$. The increase of the period of the isolated system will lead to a substantial decrease of the seismic design forces, corresponding to a design acceleration of $0.09 \mathrm{~g}$ for the elastic response. In addition, due to the isolation of the ground, the requirement for supplementary reinforcement of the columns is kept to a minimum; the foundation does not require any strengthening and the inter-storey deflections become minimum, enabling the building to behave as a rigid body.

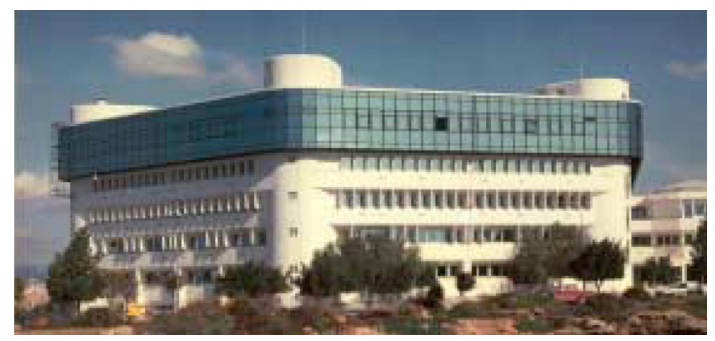

Figure 7: Central administration building of the Cyprus Telecommunications Authority.
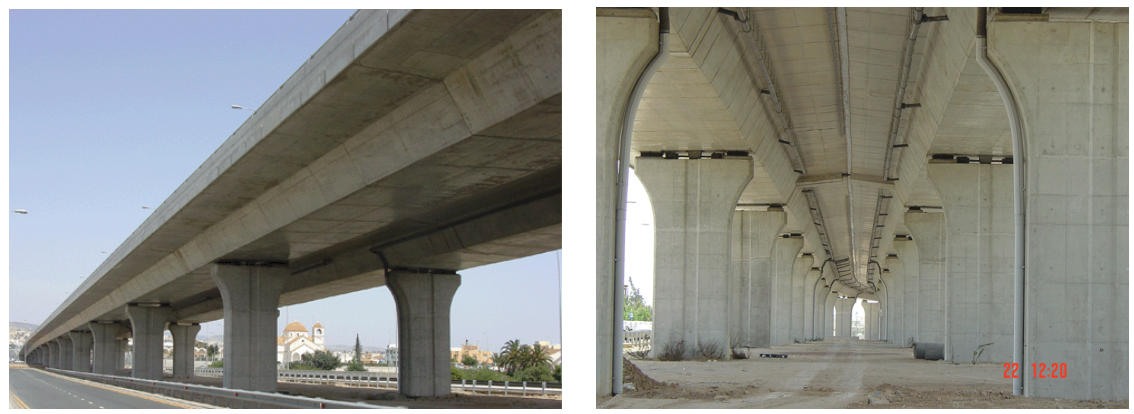

Figure 8: Bridge sector with elastomeric bearings with dual lead cores.

Highway bridges, which have been recently constructed as junction overpasses on the outskirts of Limassol, are supported on elastomeric bearings with dual lead cores, fig. 8. The bearings have rectangular shapes with dimensions ranging from $600 \times 600$ to $900 \times 850 \mathrm{~mm}$. Their maximum vertical load capacity varies from 5.5 to $12.1 \mathrm{MN}$, while their maximum horizontal relative displacements range from 185 to $270 \mathrm{~mm}$.

Similar elastomeric bearings with dual lead cores have been implemented in another highway bridge sector, Mesa Geitonia, north-east of Limassol, as shown in fig. 9.

Friction Pendulum Bearings have been installed at another overpass highway bridge in Limassol and the Amathos river bridges, fig. 10. The pier bearings installed, have a displacement capacity of $280 \mathrm{~mm}$ and an effective stiffness of $5.34 \mathrm{MN} / \mathrm{m}$. The abutment bearings have a displacement capacity of $318 \mathrm{~mm}$ and an effective stiffness of $1.7 \mathrm{MN} / \mathrm{m}$. 

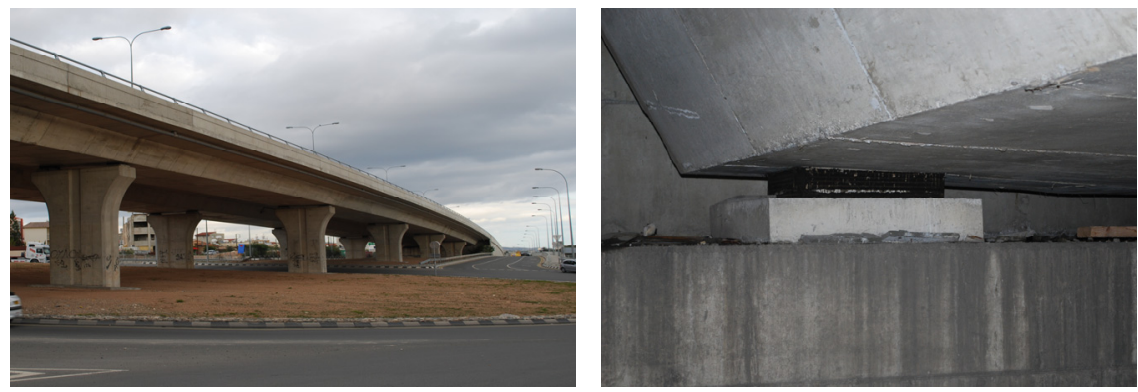

Figure 9: Elastomeric bearings with dual lead cores for another bridge sector.
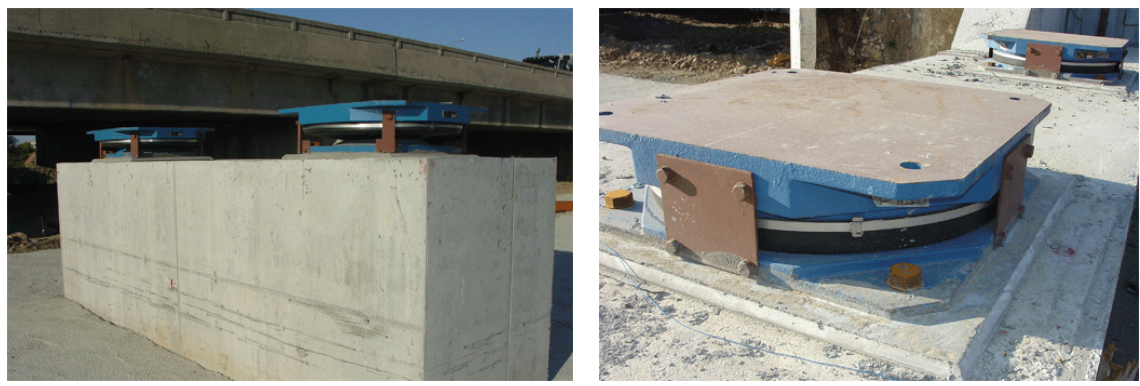

Figure 10: Friction pendulum bearing for a bridge sector.

\section{Conclusions}

An overview of the current situation regarding code provision and application in earthquake resistance issues in Cyprus proves that an immense improvement in the design, implementation and development of modern control techniques may be observed over the past years. The new national regulations on the basis of Eurocode 8 will increase the awareness in practice towards a performance-based design for structural safety. Based on the presented overview of applications of energy dissipation systems and seismic isolators in Cyprus, it is expected that applications of passive control techniques in new and existing buildings will exponentially increase in the next years.

\section{References}

[1] Ambraseys, N.N., The Seismic History of Cyprus. Department of Civil Engineering, Imperial College of Science, Technology and Medicine, London, 1963.

[2] McKenzie, D.P., Active Tectonics of the Mediterranean Region. Geophysical Journal of the Royal Astronomical Society, 30, 109-185, 1972. 
[3] Ambraseys, N.N. \& Adams, R.D., Seismicity of Cyprus Region. Ambraseys N.N. (ed.), Seismicity of Cyprus Region. ESEE Research Report, 92/09, $47-$ 66: Imperial College, London, 1992.

[4] CYS EN 1998-1:2005 Eurocode 8: Design of Structures for Earthquake Resistance. Part 1: General Rules, Seismic Actions and Rules for Buildings. Eurocodes Committee, Ministry of Interior / Technical Chamber of Cyprus.

[5] Sigaher, A.N. \& Constantinou, M.C., Scissor-Jack-Damper Energy Dissipation System. Earthquake Spectra, 19, 133-158, 2003.

[6] Sophocleous, A., Kannas, I., Karambatsos, I. \& Mylonas, K., Application of Seismic Isolation in Existing Structures as a Mean for their Essential Seismic Upgrade. 14th Hellenic Concrete Congress: Kos, 2003 [in Greek]. 